\title{
Teacher education research in the UK: the state of the art
}

\author{
Ian Menter, Moira Hulme, Jean Murray, Anne Campbell, Ian \\ Hextall, Marion Jones, Pat Mahony, Richard Procter and Karl \\ Wall ('The Teacher Education Group', TEG)
}

This paper offers an analysis of the current state of teacher education research in the United Kingdom (UK). It commences with a brief historical overview of developments over the last century. Some recent "capacity building" initiatives designed to enhance and develop teacher education research are described. There is then a focus on a particular web-based resource that draws together a significant number of publications in UK teacher education research from 2000-2008. This database is then analysed in order to identify in which journals and by which authors this work is produced. The range of methodological approaches and substantive areas of focus that appear to predominate in teacher education research in the UK are reviewed, according to categories within the database. This demonstrates that there are some very real challenges to be faced by teacher education researchers in the years ahead, similar but not identical to those faced elsewhere.

\section{Introduction}

The quality of education research in the United Kingdom has been the subject of much discussion and debate over recent times. This was in part stimulated by strident critiques by prominent individuals, particularly in England. Such critiques focused variously on the lack of relevance to practitioners, the lack of particular «scientific» approaches and the lack of rigour (see Whitty, 2006, for a summary). But these discussions have also been stimulated by the Research Assessment Exercise (RAE), a UK-wide process that takes place every 6-8 years which is designed to enable government funding bodies to make allocations to universities in proportion to the quality of the research carried out in each one. The RAE assesses the quality of research in each of 67 disciplines as submitted by 132 higher education institutions. Education is one of these 67 subjects. 81 of the 132 institutions made an education submission in 2008 .

There are estimated to be more than five thousand staff working as academics in departments or faculties of education in the UK. This makes it the second lar- 
gest subject area of all (after "Business and Management»). Nevertheless in the recent RAE carried out in 2008, only 1696 people, that is about a third of the total, were returned as being research active ${ }^{1}$. This was one of the smallest proportions of research activity for any subject. This dubious distinction is shared with a number of applied or professionally-based subjects, such as social work or nursing. The judgements made about the quality of educational research in the RAE however, suggest that a very significant proportion of the work being done is of international quality. Indeed there appears to have been a significant improvement in the quality of education research since the previous RAE which was administered in 2001 (see Gilroy \& McNamara, 2009). In spite of this improvement, the average grade awarded to education research is the fourth lowest of all 67 subjects.

The RAE thus highlights questions both about the volume and the quality of research activity (see Bridges, 2009, for a major critique of the approach taken). A number of initiatives have been undertaken over recent years that seek to improve both "capacity» and "quality» in education research. If these opening remarks have referred generally to education research in the UK, where does teacher education research in particular - this being the focus of the present paper - fit into this picture? The vast majority of the five thousand staff who are employed in education departments by universities across the UK are employed first and foremost as teacher educators, that is, the bulk of their working time is spent in the preparation, management, teaching and assessment of programmes of pre-service and in-service teacher education. The great majority of these lecturers have had a significant professional teaching career within the school or college sector before gaining employment in higher education. Just a small minority of them hold doctorates when they are appointed to university posts (and this contrasts strongly with the conventional career path of university staff in most disciplines).

In many university education departments a deep tension exists between the different priorities of the university as a whole, which emphasise the development of research excellence, thereby raising the prestige and reputation of the institution, in a drive to improve research funding levels. In education departments, this can appear to conflict with the need to deliver high quality taught programmes, that, in England at least, are subject to very rigorous inspection procedures, the outcomes of which determine allocation of resources. There is therefore something of a dual economy of teaching and research and a corresponding dual labour market within many, probably most, university education departments. The problem in the UK may be exacerbated by the continuing difficulty in securing an understanding of the integral relationship of teaching and research, that is now accepted more fully in many other contexts, including Scandinavia (see Niemi, 2008) and Switzerland (see Hofstetter \& Schneuwly, 2002). 
In order to resolve this tension, there have been many efforts to bring in a social practices model of research development. Teacher educators are introduced to research activity through researching either their own practice directly or through researching matters that are very closely related to their teacher education work (see a special issue of Journal of Education for Teaching, 2009, for examples). The extent to which this has been successful is in part what this paper is concerned with. However it may be noted that one of the remarks made in the 2008 RAE report on Education by the panel who reviewed the submissions, is that research in teacher education was one area which "was less strongly represented" than it had been in 2001 (Higher Education Funding Council for England, 2009).

The final point to be made by way of introduction is that while externally the United Kingdom may be perceived as a single political entity, in terms of the organisation and delivery of education, it is in fact four distinct systems. Education policy and practice in the four jurisdictions has been distinctive for many years, but this distinctiveness has been increased since the recent devolution of most education policy-making from the UK government to the administrations of each of the three smaller jurisdictions - Northern Ireland, Scotland and Wales at the end of the twentieth century.

In this paper we summarise some recent initiatives that are designed, at least in part, to enhance and develop teacher education research across the UK. We then describe a particular research capacity initiative that the authors of this paper have been involved with, namely a web-based resource that draws together a significant number of publications in UK teacher education research from 2000-2008. This is followed by a review of the material in this database to indicate the patterns of methodological approaches and substantive areas of focus that appear to predominate in teacher education research in the UK. This demonstrates that there are some very real challenges to be faced by teacher education researchers in the years ahead. It appears that teacher education research in the UK has quite a different character to much other highly rated education research in the UK (Torrance, 2008). However it also appears to be very different in character from teacher education research that is carried out in other parts of Europe and to much of the work in the USA and Australasia. The main criticisms of the UK research are that the work tends to be undertheorised and has an emphasis on «reflection", rather than being underpinned by more developed research methodologies.

In theoretical terms, the pattern of teacher education research in the UK, if it can be said to represent a "community of practice» (Wenger, 1999) or a collaborative "community of enquiry» (Cassidy et al., 2008) at all, would seem to be a somewhat fragmented and incoherent community. Or, in the terms developed by Becher and Trowler (2001), when reviewing the sociology of academic life in universities, while we may be reasonably clear about the "territory» of teacher education, the extent to which a self-defining academic «tribe» has been established is not so clear. 


\section{UK Teacher education research in the Twentieth Century: an overview}

Within the broad discipline of educational research, teacher education research appears to be a relatively under-developed area, without a strong theoretical or methodological tradition. Furthermore, teacher education research is often conducted by those who are also its practitioners, whether as teacher educators, managers or policy analysts of teacher education and training programmes. The history of research on teacher education is therefore also about research in teacher education. It is intricately related to the trajectory, over time, of teacher educators as an ill-defined, under-researched and sometimes beleaguered occupational group within Higher Education.

Reading histories of particular institutions can reveal some of the research interests that were dominant, but it commonly seems that the focus was on curriculum development and to a lesser extent on learning and teaching or practices of teacher education (e.g. Aldrich, 2002; Kirk, 1985). The few exceptions to this included well researched accounts of teacher education policy (for example Alexander, Craft \& Lynch, 1984; Dent, 1977) and, during the second half of the twentieth century, empirical work on the nature of teaching carried out, among others, by Morrison and McIntyre (1972).

Teacher research, practitioner research and action research have all been influential in teacher education, although perhaps less consistently than might be expected given the early emergence of such approaches in the UK through the seminal work of Stenhouse in the 1970s (Stenhouse, 1975). Also, during the 1970 s and 80s, further attempts were made to learn about effective practices in teaching through empirical classroom-based work, perhaps best exemplified by the work of Wragg (1994) and Bennett and Carré (1993). Policy developments in the 1980s and then upheavals in the 1990s gave rise to a new wave of policy related research, most notably the Modes of Teacher Education (MOTE) projects (Furlong, Barton, Miles, Whiting \& Whitty, 2000; Furlong, Hirst, Pokklington \& Miles, 1988). There has also been a fertile source of developmental research into teacher education practice at the University of Oxford, associated with McIntyre, Hagger, Furlong and others (Hagger \& McIntyre, 2006).

A research support infrastructure has also developed over this period. The Journal of Education for Teaching, now in its 35th volume, is published in the UK but with an international ambit. Other UK-based journals also emerged at about the same time, such as Teachers and Teaching and Professional Development in Education (formerly The Journal of In-Service Education). Other important structures for teacher education research included the Universities Council for the Education of Teachers, and two national educational research associations, the British and Scottish Associations (BERA and SERA), which formed specialist groups on teacher education research as late as 2005 and 2008 respectively. 
In summary then, it is clear that, even if the sub-field is not as strong and mature as some others in the UK, there is nevertheless a tradition of research in and on teacher education in the UK, which has generated several significant studies, and a supporting infrastructure such as journals, conferences and networks. We turn now to look in more depth at the recent past and some contemporary developments.

\section{UK Teacher Education research in the $21 \mathrm{st}$ Century}

The early 21st century has seen some major efforts to improve the quality of education research through capacity building. The largest of these, the Teaching and Learning Research Programme (TLRP), was a major investment in education research in the UK, running from 1999 until 2009. Total funds of well over $£ 30$ million were provided by a range of national bodies including the Economic and Social Research Council (ESRC) (which coordinated the programme), the Higher Education Funding Council for England, and the governments of England, Northern Ireland, Scotland and Wales. More than 100 major research projects and numerous smaller scale activities were funded over this period, including several that focused quite directly on teacher education and/or teacher development (see McNally \& Menter, 2009, for a review of some of these). More recently a short-term initiative, again funded by the ESRC, has developed in the northwest of England, to support the development of research capacity in the seven teacher education institutions in that region.

In Scotland, the Applied Educational Research Scheme (AERS) ran over a very similar timescale and was supported by $£ 2 \mathrm{~m}$ from central sources to run four networks which sought to bring education researchers together to work on projects related to the National Priorities in Education. One of these networks was concerned with Learners, Learning and Teaching and led to a range of work on teacher education and development (Christie \& Menter, 2009). More recently a similar generic education research network has been established in Wales (Tanner \& Davies, 2009) and a regional network specifically promoting teacher education research has been developed in the Northwest of England (Murray, Jones, McNamara \& Stanley, 2009).

In response to encouragement from the TLRP Capacity Building Initiative, the authors established a working group in 2006, called the Teacher Education Group (TEG). TEG has developed a web-based resource focussing on teacher education research in the UK, consisting of a set of online research training resources produced during Phase 2 of the TLRP's Capacity Building Programme. As Rees, Baron, Boyask and Taylor (2007, p. 776) identify, this phase is based on an "embedded social practices» model which aims to develop research capacity through engagement with already existing «communities of practice» within pro- 
fessional associations, including teacher education. The TEG initiative illustrates how this can be achieved. It has received additional funding from three national organisations with a strong interest in teacher education research. A particular concern was how the generic research resources developed during Phase 2 of the TLRP capacity building programme would need to be supplemented to ensure relevance for capacity building specifically in the field of teacher education ${ }^{2}$.

There is a general consensus that an essential part of research capacity building is the provision of adequate support and opportunities to develop expertise by acquiring new skills, knowledge and understanding of research. However, to achieve this objective, an initiative such as TEG needs to take into account the socio-cultural contexts for research and scholarship within the university departments of education (UDE) where many researchers work (Rees et al., 2007, p.776). This aspect is of particular relevance to teacher education communities where most of the research is generated by those who are also the practitioners, as indicated above (Furlong, 2007; Munn, 2008). It is thus from this dual perspective that the TEG initiative was conceived. By placing the resource on the internet it could be available as a free educational good. The resulting database and user interface were then developed into the form now available as the TEG Bibliography, hosted at the TLRP web site (www.tlrp.org/teg) ${ }^{3}$. Currently, the resource contains 446 items (i.e. details of 446 journal articles), which can be retrieved via a number of routes:

- using a range of filters (core categories and core methods);

- conducting a free word search facility;

- downloading a citation list organised by «author», «journal», «year»;

- clicking on direct links embedded in the thematic "walkthroughs».

The existing database provides a resource through which we can assess the state of health of contemporary UK research in and on teacher education. In the next section we focus respectively on the volume and locations of research, the range of methods deployed and the substantive foci of the research.

\section{Volume and locations of teacher education research, 2000-2008}

The volume of articles relating to teacher education published each year within the chosen journals almost doubled within the period 2000 to 2008, rising from 40 articles in 2000 to 79 for 2008 . This rate is likely to have been influenced by the timing of the RAE. The period 2003-2007 sees a significant year-on-year increase, peaking at 81 articles in 2007 (see Table 1). 
Table 1: Articles retrieved for inclusion, 2000-2008

\begin{tabular}{|l|r|r|}
\hline Year of publication & Frequency & $\%$ \\
\hline YR 2000 & 40 & 9 \\
\hline YR 2001 & 30 & 6.7 \\
\hline YR 2002 & 43 & 9.6 \\
\hline YR 2003 & 26 & 5.8 \\
\hline YR 2004 & 30 & 6.7 \\
\hline YR 2005 & 45 & 10.1 \\
\hline YR 2006 & 72 & 16.1 \\
\hline YR 2007 & 81 & 18.2 \\
\hline YR 2008 & 79 & 17.7 \\
\hline Total & 446 & 100 \\
\hline
\end{tabular}

The literature search revealed that UK research on teacher education is published in a wide range of education journals. A total of 42 journals were listed (see Table 2). Indeed, very few of the journals that we searched did not include at least one article on teacher education. There is a small number of journals with a strong focus on teacher education. Almost two fifths of the articles $(39.7 \%)$ included in the bibliography appeared in six journals: the Journal of In-Service Education ( 45 articles, $10.1 \%$ of the total selected articles), Journal of Education for Teaching (40 articles, 9\%), British Educational Research Journal (27 articles, 6.1\%), Teaching and Teacher Education (26 articles, 5.8\%), the European Journal of Teacher Education (24 articles, 5.4\%) and the Scottish Educational Review (23 articles, 5.2\%). The first two listed here include almost a fifth of all the articles.

Table 2: Articles selected for inclusion organised by journal, 2000-2008

\begin{tabular}{|l|c|c|}
\hline Journal & $\begin{array}{c}\text { No. of articles } \\
\text { included }\end{array}$ & $\%$ \\
\hline Journal of In-Service Education & 45 & 10.1 \\
\hline Journal of Education for Teaching & 40 & 9 \\
\hline British Educational Research Journal & 27 & 6.1 \\
\hline Teaching and Teacher Education & 26 & 5.8 \\
\hline European Journal of Teacher Education & 24 & 5.4 \\
\hline Scottish Educational Review & 23 & 5.2 \\
\hline Research Papers in Education & 18 & 4 \\
\hline Teacher Development & 16 & 3.6 \\
\hline Journal of Education Policy & 16 & 3.6 \\
\hline Pedagogy, Culture and Society & 15 & 3.4 \\
\hline Cambridge Journal of Education & 15 & 3.4 \\
\hline Teachers and Teaching & 15 & 3.4 \\
\hline Curriculum Journal & 14 & 3.1 \\
\hline Mentoring and Tutoring: Partnership in Learning & 14 & 3.1 \\
\hline British Journal of Educational Studies & 13 & 2.9 \\
\hline Oxford Review of Education & 11 & 2.5 \\
\hline
\end{tabular}




\begin{tabular}{|l|c|c|}
\hline Oxford Review of Education & 11 & 2.5 \\
\hline Educational Review & 11 & 2.5 \\
\hline International Journal of Research and Method in Education & 9 & 2 \\
\hline Gender and Education & 9 & 2 \\
\hline British Journal of Sociology of Education & 9 & 2 \\
\hline Journal of Vocational Education and Training & 8 & 1.8 \\
\hline Journal of Further and Higher Education & 8 & 1.8 \\
\hline International Studies in Sociology of Education & 8 & 1.8 \\
\hline Professional Development in Education & 7 & 1.6 \\
\hline Educational Studies & 7 & 1.6 \\
\hline Educational Action Research & 6 & 1.3 \\
\hline Research in Post-Compulsory Education & 4 & 0.9 \\
\hline Irish Educational Studies & 4 & 0.9 \\
\hline Educational Research & 4 & 0.9 \\
\hline Research in Education & 3 & 0.7 \\
\hline Welsh Journal of Education & 2 & 0.4 \\
\hline Journal of Post Compulsory Education & 2 & 0.4 \\
\hline Journal of Education and Work & 2 & 0.4 \\
\hline Journal of Curriculum Studies & 2 & 0.4 \\
\hline European Journal of Educational Research & 2 & 0.4 \\
\hline Management in Education & 1 & 0.2 \\
\hline International Journal of Educational Research & 1 & 0.2 \\
\hline Higher Education Review & 1 & 0.2 \\
\hline Higher Education Quarterly & 1 & 0.2 \\
\hline Educational Research and Evaluation & 1 & 0.2 \\
\hline Educational Philosophy and Theory & 446 & 0.2 \\
\hline Disability and Society & & 0.2 \\
\hline Total & 100 \\
\hline
\end{tabular}

A large number of the authors contribute to published work in teacher education within the journals reviewed but higher levels of research activity appear concentrated among a relatively small core of active researchers located in particular institutions. 581 authors contributed towards the 446 articles selected for inclusion in the resource (see Table 3). Of these, three-quarters contributed towards only one article that satisfied the inclusion criteria $(n=433,74.5 \%)$. In the nineyear period of the review, encompassing two Research Assessment Exercises, only 28 individuals (4.8\% of the total) authored or co-authored more than four articles included in the resource. Three of these authors are currently employed in post-1992 «new» universities 4 that were formerly "polytechnics» and two are based in universities that were formerly colleges of higher education (these were given university status even more recently $)^{5}$. The remaining 23 authors $(82.1 \%$ of the more productive authors) were employed in established research universities, including nine authors $(32.1 \%)$ working in three "ancient» universities ${ }^{6}$ and five authors (17.8\%) working in four «red brick» universities ${ }^{7}$ (British universities receiving university status prior to World War One through the civic university movement). The highest concentration of more productive authors since 2000 within a single institution was at Oxford University, with five authors. 
Table 3: Publications per individual author in the TEG bibliography, 2000-2008

\begin{tabular}{|c|c|c|}
\hline $\begin{array}{c}\text { Number of } \\
\text { articles }\end{array}$ & $\begin{array}{c}\text { Number of } \\
\text { authors with this } \\
\text { number of articles }\end{array}$ & \% of authors \\
\hline 13 & 1 & 0.2 \\
\hline 12 & 0 & 0 \\
\hline 11 & 1 & 0.2 \\
\hline 10 & 0 & 0 \\
\hline 9 & 1 & 0.2 \\
\hline 8 & 2 & 0.3 \\
\hline 7 & 6 & 1 \\
\hline 6 & 7 & 1.2 \\
\hline 5 & 10 & 1.7 \\
\hline 4 & 11 & 1.9 \\
\hline 3 & 34 & 5.9 \\
\hline 2 & 75 & 12.9 \\
\hline 1 & 433 & 74.5 \\
\hline Total & 581 & 100 \\
\hline
\end{tabular}

The vast majority of articles selected for inclusion in the TEG resource address teacher education contexts in England, which is by far the largest provider of teacher education in the UK (76 HE institutions provide pre-service teacher education through a variety of routes) (see Table 4). These papers largely relate to the policy context governing teacher education in England and Wales. Whilst the distribution of articles by national context reflects the scale of provision in each of the four countries of the UK, it also appears influenced by research capacity, with Scotland emerging as a small country with a relatively strong record in teacher education research. Seven of the 28 more productive authors (25\%) were working in three universities in the west of Scotland ${ }^{8}$. None of the authors with a higher rate of publications included in the TEG resource is based in a university in Wales or Northern Ireland.

There are seven providers of initial teacher education in Scotland, all of them are universities. Six of the seven education departments in these universities are the result of mergers with former freestanding colleges of education (see Kirk, 2003; Menter, 2008). Sixty-four (64) articles within the TEG resource (20002008) relate to the Scottish context, a figure that represents $14.3 \%$ of all articles included in the resource. The Scottish Educational Review, published twice per year, carried 23 articles that satisfied the inclusion criteria in the period 20002008. This figure includes a special issue on "Teacher Education and Professional Development» published in 2006. 
Table 4: Classification by UK national context outside England, 2000-2008

\begin{tabular}{|l|c|c|}
\hline National context & Frequency & $\%$ \\
\hline Wales & 6 & 1.3 \\
\hline Scotland & 64 & 14.3 \\
\hline Northern Ireland & 15 & 3.4 \\
\hline Republic of Ireland & 10 & 2.2 \\
\hline & $\mathbf{9 5}$ out of $\mathbf{4 4 6}$ & $\mathbf{2 1 . 2 \%}$ of total \\
\hline
\end{tabular}

In the period of the review, eight HEIs provided teacher education in Wales. Provision is currently subject to reconfiguration in response to the Furlong Review of Initial Teacher Education and Training (ITET), which recommended three separate centres (each with two current providers in partnership) covering North and Mid-Wales, South-West Wales and South-East Wales. Of the 446 articles for the period $2000-2008$, only six (1.3\% of the total numbers of articles) explicitly addressed the national context of Wales. Of these, three focus on policy issues relevant exclusively to Wales i.e. issues of teacher recruitment and retention (See, Gorard \& White, 2004), school-university Initial Teacher Education partnerships in a region of Wales (Bassett, 2003), and the supply of newly qualified teachers for Wales (Furlong, Hagger \& Furlong, 2007). In the nine year period covered by the literature search, the Welsh Journal of Education yielded just two articles that satisfied the inclusion criteria.

Five higher education institutions currently deliver teacher education in Northern Ireland. A review of initial teacher education in Northern Ireland by Taylor and Usher (2004) recommended rationalization of provision by bringing the two university colleges under the governance of Queen's University, Belfast. Fifteen articles within the TEG resource (2000-2008) focused on aspects of provision in Northern Ireland (3.4\% of the total number of articles, excluding «all Ireland» and cross-UK papers). In addition to articles on mentoring, partnership and professional learning, there is a stronger focus within this body of work on equity issues, inclusive education and diversity. This reflects some concern around the characteristics of the teaching profession in Northern Ireland, proposed moves away from academic selection, and attempts to widen access to teacher education (Moran, 2007, 2008; Nelson, 2008; Siberry \& Kearns, 2005)

\section{How is teacher education research in the UK carried out?}

A review of the content of the TEG resource suggests that research undertaken in the field of teacher education in the UK is more likely to be small-scale, qualitative and practice-based (see Table 5). All of the items included in the resource were assigned one or more of seventeen methodological categories that we had 
identified. Among the 446 research articles selected for inclusion, 112 (25.1\%) were classified as large-scale (broadly defined as involving more than one hundred participants), 38 (8.5\%) involved a quantitative research design and 137 papers $(30.7 \%)$ reported the findings of practice-based enquiries undertaken by university lecturers/ teacher educators. Single authors or pairs of authors working within the same institution, commonly without external funding, undertook most of the practice-based studies reported. Interviews are the most common method of data gathering (227 instances, $50.5 \%$ of papers).

Table 5: Classification organised by core methods, 2000-2008

\begin{tabular}{|l|c|c|}
\hline Core Methods & Frequency & \% of 446 items \\
\hline Reflection & 268 & 60.1 \\
\hline Interviews & 227 & 50.9 \\
\hline Small-scale & 194 & 43.5 \\
\hline Qualitative & 185 & 41.5 \\
\hline Literature review & 138 & 30.9 \\
\hline Practice-based & 137 & 30.7 \\
\hline Questionnaire & 129 & 28.9 \\
\hline Large-scale & 112 & 25.1 \\
\hline Mixed & 102 & 22.9 \\
\hline Content analysis & 100 & 22.4 \\
\hline Political economy & 100 & 22.4 \\
\hline Case study & 83 & 18.6 \\
\hline Survey & 53 & 11.9 \\
\hline Longitudinal & 38 & 8.5 \\
\hline Quantitative & 38 & 8.5 \\
\hline Action research & 35 & 7.8 \\
\hline Quasi-experimental & 3 & 0.7 \\
\hline
\end{tabular}

In the nine-year period of the review, few large-scale longitudinal studies of teacher education were undertaken in the UK. The TEG resource contains thirtytwo studies with a longitudinal dimension (8.5\% of the total number of papers). The search did not reveal research with a similar scale and scope to the Modes of Teacher Education (MOTE) project, which studied the origins, nature, and effects of reforms of initial teacher education in England and Wales between 1991 and 1996 (Furlong et al., 2000). Two major research studies were commissioned in England, which account for seven of the articles included in the TEG resource. The first of these was the project called Variations in Teachers' Work, Lives and their Effects on Pupils (VITAE) (2001-2005), commissioned by the Department for Children, Schools and Families (DCSF) to identify factors that affect teachers' work lives over time and the effect of these on their teaching and pupil progress (see Day \& Gu, 2007; Day, Stobart, Sammons \& Kington, 2006a; Day, 
Kington, Stobart \& Sammons, 2006b; Gu \& Day, 2007; Sammons et al., 2007). The second major longitudinal study was the Becoming a Teacher Project (BaT), a six-year longitudinal research project (2003-09) focusing on the experiences of teachers entering the profession through a variety of routes during their initial teacher training (ITT), induction and early professional development (Hobson, Malderez, Tracey \& Kerr, 2005; Hobson, Malderez, Tracey \& Pell, 2006). The BaT project was funded by the Department for Children, Schools and Families (DCSF), the General Teaching Council for England (GTCE) and the Training and Development Agency for Schools (TDA).

There is little evidence of large-scale systematic research being undertaken to directly inform the on-going development of particular teacher education programmes in the UK. One notable exception is the Scottish Teachers for a New Era project (STNE) at Aberdeen University, funded by the Scottish Government and the Hunter Foundation, which proposes a six-year model of teacher education and is supported by the work of a multi-disciplinary team of researchers and practitioners (see Luby, 2006). Whilst there were no published outcomes from this developmental work in the parameters of the TEG search, this is likely to change in the future (see Gray, D., Graham, A., Dewhurst, Y., Kirkpatrick, G., MacDougall, L, Nicol, S. and Nixon, G. 2009).

The chosen methods of enquiry in the body of work selected for inclusion in the TEG resource does not suggest that the "evidence-based education» movement in the UK has had a strong impact on the field of teacher education research. The endorsement of «scientifically-based research" techniques evident in North America is not apparent in the design of studies included in the TEG resource' (Menter, 2009). Only two studies are classified as "quasi-experimental». Lawson, Harrison and Cavendish (2004) used pre- and post-test questionnaires with a control and experimental group in their study of the influence of Individual Action Planning on pre-service teacher preparation. Brooks (2006) used a quasi-experimental design, involving a naturally occurring "treatment» and control group, in her evaluation of the impact of a Training School ${ }^{10}$ in England.

There are well-documented critiques of the transfer of the «medical model» to educational research, which are beyond the scope of this article (MacLure, 2005; Torrance, 2004). Furlong (2004) has encouraged education researchers to "rise above» the divisiveness of "paradigm wars» (Anderson \& Herr, 1999). The TEG resource includes 102 studies that draw on a combination of methods $(22.8 \%$ of the total). As previously noted, few of these studies are large-scale or longitudinal, a notable exception being the Effective Provision of Pre-School Education (EPPE) Project at the Institute of Education, London (1997-2008) (Siraj-Blatchford, Sammons, Taggart, Sylva \& Melhuish, 2006). There is a developing portfolio of work at the Centre for Effective Education, Queen's University Belfast (Connolly et al., 2006; Connolly \& Hoskin, 2006), the Curriculum Evaluation and Management Centre (CEM) at Durham University (Coe, Fitz-Gibbon \& Tymms, 2000), and the Institute of Effective Education at York University (Slavin, 2008). 
The National Foundation for Educational Research and the Evidence for Policy and Practice Information and Co-ordinating Centre (EPPI-Centre) have undertaken systematic reviews involving meta-analysis of randomised controlled trials and cluster trials in specific areas of education. The complexity of conducting "pure» RCTs in education settings has resulted in a shift in EPPI-Centre protocols and the broader category of «researcher manipulated intervention» being used in the keywording system. In contrast with North American models, randomised control trials (RCTs) in education in the UK are more likely to form part of multiple-method approaches, combining quantitative measurement of impact with qualitative process studies (Oakley et al., 2003; Stephenson et al., 2004). The literature search conducted in compiling the TEG resource reveals that teacher education research has yet to engage with these approaches on any significant scale.

\section{What are the substantive areas for teacher education research in the UK?}

When establishing the database we identified eight particular topic areas that we judged were significant, as listed in Table 6. Not surprisingly, professional learning dominates the choice of topics undertaken in teacher education research. $85.2 \%$ of articles $(n=380)$ included in the TEG resource address issues of professional learning. Among these papers, professional learning is most frequently used in relation to school teachers - beginning teachers (pre-service, induction or early career teachers) or mentors/supporters in school settings (experienced/ veteran teachers supporting novice teachers in the practicum/field experience). 256 papers focus on the regulatory frameworks and policies that govern teacher education in the UK. Of these, 148 (33.2\% of the total) focus on curriculum and assessment, and 110 (24.7\% of the total) focus on partnership relations between schools and providers of teacher education.

Table 6: Classification organised by core topics, 2000-2008

\begin{tabular}{|l|c|c|}
\hline Topics & Frequency & \% of 446 items \\
\hline Professional Learning & 380 & 85.2 \\
\hline National Context & 367 & 82.3 \\
\hline Regulatory frameworks and policy & 256 & 57.4 \\
\hline Curriculum and assessment & 148 & 33.2 \\
\hline Partnership & 110 & 24.7 \\
\hline Equity issues & 77 & 17.3 \\
\hline Ethical issues & 52 & 11.7 \\
\hline Teacher educators' professional development & 52 & 11.7 \\
\hline
\end{tabular}


In mapping the field of teacher education research in the UK, two of the eight identified topics received significantly less attention: (1) teacher educators' professional development; and (2) ethical issues including the ethics of education, the "ethical teacher», and the ethical conduct of educational research. Of the 446 articles selected for inclusion in the period 2000-2008, only 52 (11.7\% of the total) in each case were classified as explicitly addressing teacher educators' professional development or ethical issues as a significant focus of the article. Relatively few articles explicitly address the question of ethics in the conduct of teacher education research, which may be a cause for concern given the volume of small-scale studies conducted by teacher educators that involve students/mentees and other school-based partners. Among the few studies addressing ethical issues in research practice in the context of teacher education, Jones \& Stanley (2008) consider the issue of «informed consent» in school-university collaborative research. Sikes (2006) reflects on the factors influencing the decisions taken by researchers who undertake educational research; and Wilkins (2000) discusses ethical issues arising from the promotion of local authority-led practitioner research. The literature search identified a small number of articles that address philosophical questions of ethical standards in teaching and notions of the «ethical teacher» (Campbell, 2001; Carr, 2007; Erben, 2000; Scott-Baumann, 2006).

\section{Discussion and conclusions}

Mapping the field of teacher education research, according to the protocol of the TEG search, raises a number of issues.

- Much teacher education research remains small-scale, qualitative and practice-based. The high volume of single studies and the paucity of large-scale, longitudinal studies reduce the potential cumulative and developmental impact of research on and for teacher education in the UK. A similar conclusion was reached by Murray, Campbell et al (2008) in their review of teacher education research in Australia. It may also be noted that this kind of piecemeal, small-scale research is very different from that education research in the UK that is funded by the ESRC, which is found both to be of excellent quality and conducted by a relatively small number of scholars, concentrated in a small number of universities (Torrance, 2008).

- Moreover, there is relatively little attempt to theorise within this body of work. The research is largely practice-oriented, pragmatic and/or developmental, rarely invoking theory either in methods or in terms of the analysis of findings. This contrasts not only with research carried out elsewhere but with much other education research in the UK. Methodological weaknesses were also found to be a feature of teacher education research in New Zealand (Cameron \& Baker, 2004). 
- The search revealed different patterns of productivity according to national context and affiliation, with Scotland, where all pre-service teacher education is university-led, emerging in a relatively strong position for a small country. If production of articles included in the TEG resource is an indication of research capacity, then Wales and Northern Ireland, both currently subject to a re-configuration of providers, do not fare as well as their neighbours.

- There is little evidence to suggest a shift towards multiple methods that include quasi-experimental designs in teacher education research in the UK. North American models of «scientifically-based» or "scientistic» research (CochranSmith \& Lytle, 2009) are not evident in the UK.

- The professional education of teacher educators is an under-researched area.

- Given the high volume of small-scale, practice-based studies undertaken by teacher educators, the ethics of conducting practitioner research in teacher education is a neglected area.

In spite of systematic and state-sponsored teacher education having a long history (dating back into the 19th century) teacher education research is but a young sub-field of education research more generally. The UK is not alone in experiencing the absence of coordinated programmes of teacher education research, nor in having a preponderance of small-scale, "one-off» under-theorised studies. Even in the USA, where the field is arguably the most advanced and where there has been a number of longitudinal and experimental studies carried out, there is still a lack of coherence, as indicated by Cochran-Smith and Zeichner (2005), as they review the situation there:

[...] we believe that we are at a turning point in the field. As a field, we now need to develop a rich portfolio of theory-driven studies... We need to develop accurate national databases that make many kinds of cross-institutional and multivariate analyses possible. We need to initiate multi-site studies that link multiple smaller studies in ways that reveal the impact of differing contexts and conditions [...] (p. 2)

The findings from our UK analysis do help to define a similar agenda for future research in teacher education. The need for greater coordination, programming and resourcing is even more pronounced in the UK where, as we have seen, there are very few large-scale and/or longitudinal and/or theoretically informed studies. Important questions about resources, organisation and development remain. The various schemes mentioned in the earlier sections of this paper are mainly short-term or have already concluded. A UK-wide Strategic Forum for Research in Education (see Torrance, 2008) is seeking to build on what has been achieved in order to make it more sustainable. This Forum is not limited to teacher education research but is distinctive in bringing together researchers, practitioners ${ }^{11}$ and policy-makers, including those concerned with teacher education. The British Educational Research Association and the Scottish Educational 
Research Association each have a specialist grouping around teacher education as does the UCET ${ }^{12}$ Research and Development Committee which continues to monitor and support developments of these kinds. The outcomes of the activities of the Teacher Education Research Network (TERN) are awaited with interest - it was one of two pilot schemes to be supported by the Economic and Social Research Council commencing in January 2009 (Murray et al., 2009). One possibility is that it, or something like it, will be "rolled out» across the UK but it is certainly difficult to see where the funds would come from for a major expansion, at a time of diminishing resources for higher education and research.

The other crucial element in the future development of teacher education research in the UK is that it must also have an outward looking approach. The Network on Teacher Education Research that is part of the European Educational Research Association is an important forum for development, as is the Association of Teacher Educators in Europe, and there is much to be gained both by comparative research across Europe and beyond, but also more generally by collaboration between researchers in different national contexts. As Hanele Niemi has put it, when considering the European scene:

\section{Teacher education in itself should also be an object of study and research. This research should provide knowledge about the effectiveness and quality of teacher education implemented by various means and in different cultural contexts. (Niemi, 2008, p. 204)}

Finally, it is important to emphasise that although the selection of items for inclusion in the TEG bibliography was based on a number of criteria, neither the actual quality of the research reported in each paper nor indeed the quality of each paper per se, were judged by the team. Nevertheless, as we move towards an increasingly metrics-oriented approach to quality assessment in the UK (and perhaps in Europe as well, following EERQI'13) (Bridges, 2009), it seems likely that the production of this kind of resource may have some significant indirect impact on judgements about the quality of research.

\section{Notes}

1 The figures used here are drawn from presentations made to the Research \& Development Committee of the Universities' Council for the Education of Teachers (UCET) by Margaret Brown King's College, London and John Furlong, University of Oxford in 2009.

2 The development of the TEG resource is described more fully by Murray, Campbell et al., (2008).

3 The website will also be available through the British Educational Research Association (www.bera.ac.uk).

4 Huddersfield, East London and Liverpool John Moores.

5 Winchester and Roehampton.

6 Glasgow, Oxford and Cambridge.

7 Manchester, Birmingham, Nottingham and Leicester. 
8 Glasgow, Strathclyde, and Paisley.

9 Early trials-based research in education in the UK tended to focus on health issues such as health promotion and was predominantly published in North American and health-oriented publications (Oakley et al., 2003; Stephenson et al., 2004).

10 Training Schools were introduced through the Green Paper, Teachers - Meeting the challenge of change (Department for Education and Employment, 1998). These schools receive an additional resource to focus on the provision on school-led initial teacher training in England.

11 One further aspect for consideration as we look to future development - and this has not been focussed on in this paper - is the need for closer collaboration between researchers and practitioners. Indeed, practice-based research and practitioner research may be crucial to the successful development of teacher education research. It may be that integration of research dimensions into the practice of teaching (including teaching education) will prove to be a key element.

12 The Universities' Council for the Education of Teachers is a UK wide lobby group.

13 EERQI - the European Education Research Quality Indicators project, led by Prof Ingrid Gogolin at the University of Hamburg.

\section{References}

Aldrich, R. (2002). The institute of education 1902-2002. A centenary history. London: Institute of Education.

Alexander, R., Craft, M. \& Lynch, J. (Ed.). (1984). Change in teacher education: Context and provision since Robbins. London: Holt, Winston and Rinehart Ltd.

Anderson, G. L. \& Herr, K. (1999). The new paradigm wars: Is there room for rigorous practitioner knowledge in schools and universities. Educational Researcher, 28, 12-21.

Bassett, P. (2003). Initial teacher education and training: A new opportunity for partnership in Wales. Welsh Journal of Education, 12 (3), 4-12.

Becher, T. \& Trowler, P. (2001). Academic tribes and territories: Intellectual enquiry and the cultures of disciplines. Buckingham: Open University.

Bennett, N. \& Carré, C. (Ed.). (1993). Learning to teach. London: Routledge.

Bridges, D. (2009). Research quality assessment in education: Impossible science, possible art? British Educational Research Journal, 35 (4), 497-518.

Brooks, V. (2006). A «quiet revolution»? The impact of training schools on initial teacher training partnerships. Journal of Education for Teaching, 32 (4), 379-394.

Cameron, M. \& Baker, R. (2004). Initial teacher education in New Zealand: 1993-2004. Literature review and annotated bibliography. New Zealand: Ministry of Education.

Campbell, E. (2001). Let right be done: Trying to put ethical standards into practice. Journal of Education Policy, 16 (5), 395-411.

Carr, D. (2007). Towards an educationally meaningful curriculum: Epistemic holism and knowledge integration revisited. British Journal of Educational Studies, 55 (1), 3-20.

Cassidy, C., Christie, D., Coutts, N., Dunn, J., Sinclair, C., Skinner, D. \& Wilson, A. (2008). Building communities of educational enquiry. Oxford Review of Education, 34 (2), 217 235.

Christie, D. \& Menter, I. (2009). Research capacity building in teacher education: Scottish collaborative approaches. Journal of Education for Teaching, 35 (4), 337-354.

Cochran-Smith, M. \& Lytle, S. L. (Ed.). (2009). Inquiry as stance. Practitioner research for the next generation. New York: Teacher College Press.

Cochran-Smith, M. \& Zeichner, K. (Ed.). (2005). «Executive Summary». In M. CochranSmith \& K. Zeichner (Ed.), Studying teacher education: The report of the AERA panel on research and teacher education (pp. 1-36). New Jersey: Erlbaum. 
Coe, R., Fitz-Gibbon, C. \& Tymms, P. (2000, September). Promoting evidence-based education: The role of practitioners. Round table presented at the British Educational Research Association. Cardiff University.

Connolly, P., Fitzpatrick, S., Gallagher, T. \& Harris, P. (2006). Addressing diversity and inclusion in the early years in conflict-affected societies: A case study of the Media Initiative for Children - Northern Ireland. International Journal of Early Years Education, 14 (3), 263-278.

Connolly, P. \& Hoskin, K. (2006). The general and specific effects of educational programmes aimed at promoting awareness of and respect for diversity among young children. International Journal of Early Years Education, 14 (2), 107-126.

Day, C. \& Gu, Q. (2007). Variations in the conditions for teachers' professional learning and development: Sustaining commitment and effectiveness over a career. Oxford Review of Education, 33 (4), 423 - 443.

Day, C., Stobart, G., Sammons, P. \& Kington, A. (2006a). Variations in the work and lives of teachers: Relative and relational effectiveness. Teachers and Teaching: Theory and Practice, $12(2), 169-192$.

Day, C., Kington, A., Stobart, G. \& Sammons, P. (2006b). The personal and professional selves of teachers: Stable and unstable identities. British Educational Research Journal, 32 (4), 601-616.

Dent, H. (1977). The training of teachers in England and Wales 1800 -1975. London: Hodder and Stoughton.

Department for Education and Employment (DfEE). (1998). Teachers - Meeting the challenge of change (Green Paper). London: The Stationery Office.

Erben, M. (2000). Ethics, education, narrative communication and biography. Educational Studies, 26 (3), 379-390.

Furlong, J. (2004). BERA at 30: Have we come of age? British Educational Research Journal, 30 (3), 343-358.

Furlong, J. (2007, November). The universities and education: Where are we? How did we get here? Where should we be? Keynote address to the University Council for the Education of Teachers Annual Conference. Staverton.

Furlong, J., Barton, L., Miles, S., Whiting, C. \& Whitty, G. (2000). Teacher education in transition. Buckingham: Open University Press.

Furlong, J., Hagger, H. \& Furlong, C. (2007). Politics and evidence-based policy making: The review of initial teacher training provision in Wales. Welsh Journal of Education, 14 (1), 117-132.

Furlong, J., Hirst, P., Pocklington, K. \& Miles, S. (1988). Initial teacher training and the role of the school. Milton Keynes: Open University.

Gilroy, P. \& McNamara, O. (2009). A critical history of research assessment in the UK and its post-1992 impact on education. Journal of Education for Teaching, 35 (4), 321-335.

Gray, D., Graham, A., Dewhurst, Y., Kirkpatrick, G., MacDougall, L, Nicol, S. and Nixon, G. (2009). Scallops, schools and scholars: reflections on the emergence of a research-oriented learning project. Journal of Education for Teaching, 35, (4), 425-440.

Gu, Q. \& Day, C. (2007). Teachers' resilience: A necessary condition for effectiveness. Teaching and Teacher Education, 23 (8), 1302-1314.

Hagger, H. \& McIntyre, D. (2006). Learning teaching from teachers. Maidenhead: Open University Press.

Higher Education Funding Council for England (HEFCE). (2009). Sub-panel 45 Education Subject Overview Report. Retrieved 2 March 2010, from http://www.rae.ac.uk /pubs/2009/ov/

Hobson, A., Malderez, A., Tracey, L. \& Kerr, K. (2005). Teachers' experiences of initial teacher preparation, induction and early professional development in England - Does route matter? Journal of Education for Teaching, 31 (2), 133-135. 
Hobson, A., Malderez, A., Tracey, L. \& Pell, G. (2006). Pathways and stepping stones: Student teachers' preconceptions and concerns about initial teacher preparation in England. Scottish Educational Review, 37, 59-78.

Hofstetter, R. \& Schneuwly, B. (2002). Institutionalisation of educational sciences and the dynamics of their development. European Educational Research Journal, 1 (1), 3-26.

Jones, M. \& Stanley, G. (2008). Children's lost voices: Ethical issues in relation to undertaking collaborative, practice-based projects involving schools and the wider community. Educational Action Research, 16 (1), 131-141.

Kirk, G. (Ed.). (1985). Moray house and professional education. Edinburgh: Scottish Academic Press.

Kirk, G. (2003). Teacher education institutions. In T. G. K. Bryce \& W. M. Humes (Ed.), Scottish Education - 2nd edition: Post-Devolution (pp. 921-930). Edinburgh University Press.

Lawson, T., Harrison, J. \& Cavendish, S. (2004). Individual action planning: A case of selfsurveillance? British Journal of Sociology of Education, 25 (1), 81-94.

Luby, T. (2006). Developing professional knowledge within a community of practice: Questions for STNE. Education in the North, 14, 23-30.

MacLure, M. (2005). Clarity bordering on stupidity: Where's the quality in systematic review? Journal of Education Policy, 20 (5), 393-416.

McNally, J. \& Menter, I. (2009). Editorial. Teaching and Teacher Education, 25 (7), 941-943.

Menter, I. (2008). Teacher education institutions. In T. G. K. Bryce \& W. M. Humes (Ed.), Scottish Education - 3rd edition: Beyond Devolution (pp. 817-825). Edinburgh University Press,

Menter, I. (2009). An uneasy relationship? Teacher education research and education science. In R. St. Clair (Ed.), Education Science (pp. 41-52). Rotterdam: Sense.

Moran, A. (2007). Embracing inclusive teacher education. European Journal of Teacher Education, 30 (2), 119-134.

Moran, A. (2008). Challenges surrounding widening participation and fair access to initial teacher education: Can it be achieved? Journal of Education for Teaching, 34 (1), 63-78.

Morrison, A. \& McIntyre, D. (1972). Teachers and Teaching. Harmondsworth: Penguin.

Munn, P. (2008). Building research capacity collaboratively: Can we take ownership of our future? (BERA presidential address). British Educational Research Journal, 34 (4), 413-430.

Murray, J., Campbell, A., Hextall, I., Hulme, M., Jones, M., Mahony, P., Menter, I., Procter, R. \& Wall, K. (2008). Mapping the field of teacher education research: Methodology and issues in a research capacity-building initiative in teacher education in the United Kingdom. European Educational Research Journal, 7 (4), 459-474.

Murray, J., Jones, M., McNamara, O. \& Stanley, G. (2009). Capacity = expertise x motivation $\mathrm{x}$ opportunities: Factors in capacity building in teacher education in England. Journal of Education for Teaching, 35 (4), 391-408.

Murray, S., Nuttall, J. \& Mitchell, J. (2008). Research into initial teacher education in Australia: A survey of the literature 1995-2004. Teaching and Teacher Education, 24 (1), 225-239.

Nelson, J. (2008). Exploring diversity through ethos in initial teacher education. Teaching and Teacher Education, 24 (7), 1729-1738.

Niemi, H. (2008). Advancing research into and during teacher education. In B. Hudson \& P. Zgaga (Ed.), Teacher education policy in Europe: A voice of higher education institutions (pp. 183-208). University of Umeå, Faculty of Teacher Education, in co-operation with the University of Ljubljana, Faculty of Education, Centre for Educational Policy Studies.

Oakley, A., Strange, V., Toroyan, T., Wiggins, M., Roberts, I. \& Stephenson, J. (2003). Using random allocation to evaluate social interventions: Three recent UK examples. Annals of the American Academy of Political and Social Science, 589 (1), 170-189. 
Rees, G., Baron, S., Boyask, R. \& Taylor, C. (2007). Research capacity building, professional learning and the social practices of educational research. British Educational Research Journal, 33 (5), 761-779.

Sammons, P., Day, C., Kington, A., Gu, Q., Stobart, G. \& Smees R. (2007). Exploring variations in teachers' work lives and their effects on pupils: Key findings and implications from a longitudinal mixed-method study. British Educational Research Journal, 33 (5), 681-701.

Scott-Baumann, A. (2006). Ethics, Ricoeur and philosophy: Ethical teacher workshops. International Journal of Research and Method in Education, 29 (1), 55-70.

See, B. H., Gorard, S. \& White, P. (2004). Teacher demand: Crisis what crisis? Cambridge Journal of Education, 34 (1), 103-112.

Siberry, L. \& Kearns, H. (2005). An intercultural approach to challenging issues in Northern Ireland teacher education. European Journal of Teacher Education, 28 (3), 259-266.

Sikes, P. (2006). On dodgy ground? Problematics and ethics in educational research. International Journal of Research and Method in Education, 29 (1), 105-117.

Siraj-Blatchford, I., Sammons, P., Taggart, B., Sylva, K. \& Melhuish, E. (2006). Educational research and evidence-based policy: The mixed method approach of the EPPE Project. Evaluation and Research in Education, 19 (2), 63-82.

Slavin, R. (2008). Perspectives in evidence-based research in education: What works? Issues in synthesizing educational program evaluations. Educational Researcher, 37 (5), 5-14.

Stenhouse, L. (1975). An introduction to curriculum development. London: Heinemann.

Stephenson, J. M., Strange, V., Forrest, S., Oakley, A., Copas, A., Allen, E., Black, S., Ali, M., Monteiro, H. \& Johnson, A. M. (2004). Pupil-led sex education in England (RIPPLE study): Cluster-randomised intervention trial. The Lancet, 364 (9431), 338-346.

Tanner, H. \& Davies, S. (2009). How engagement with research changes the professional practice of teacher educators: A case study from the Welsh Education Research Network. Journal of Education for Teaching, 35 (4), 373-389.

Taylor, D. \& Usher, R. (2004). Aspects of initial teacher education in Northern Ireland. Department for Education and Learning. Retrieved May 24, 2009, from http://www.delni.gov.uk/study_of_teacher_education_in_northern_ireland_final-2.pdf

Torrance, H. (2004, June). Systematic Reviewing - The «call centre» version of research synthesis: Time for a more flexible approach. Invited presentation to ESRC/RCBN seminar on Systematic Reviewing. University of Sheffield.

Torrance, H. (2008). Overview of ESRC Research in Education. Final report of a consultancy commissioned by ESRC. Swindon, ESRC. Retrieved 2 March 2010, from http://www.sfre.ac.uk/wp-content/uploads/2009/06/esrc-uk-overview.doc

Wenger, E. (1999). Communities of practice: Learning, meaning and identity. Cambridge: University Press.

Whitty, G. (2006). Education(al) research and education policy: Is conflict inevitable? British Educational Research Journal, 32 (2), 159-176.

Wilkins, R. (2000). Practitioner research in LEA-directed INSET. Journal of In-Service, Education, 26 (1), 99-113.

Wragg, E. (1994). Effective teaching. London: Routledge.

Key words: Teacher education, United Kingdom, Research methods, Journals, research networks 


\section{Stand der Forschung über die Lehrerinnen- und Lehrerbildung in Grossbritannien}

\section{Zusammenfassung}

Der vorliegende Beitrag beschäftigt sich mit der gegenwärtigen Situation der Forschung in der Lehrerinnen- und Lehrerbildung in Grossbritannien. Einleitend geben die Autoren einen kurzen historischen Überblick über die Entwikklungen des letzten Jahrhunderts, gefolgt von der Darstellung einiger jüngster Initiativen, die auf den Kapazitätenausbau in der Lehrerinnen- und Lehrerbildungforschung abzielen. Die Basis des Artikels bildet die Analyse einer einschlägigen Online-Datenbank, die eine grosse Anzahl wissenschaftlicher Veröffentlichungen zur Lehrerinnen- und Lehrerbildung im Vereinigten Königreich für den Zeitraum 2000-2008 abdeckt. Durch die Analyse dieser bibliografischen Datenbank wird in einem ersten Schritt ermittelt, in welcher wissenschaftlichen Zeitschrift und von welchen Autoren ein Artikel veröffentlicht wurde. Die Untersuchung soll dann zeigen, welche methodischen Ansätze und welche thematischen Schwerpunkte in der Lehrerinnen- und Lehrerbildungsforschung in Grossbritannien überwiegen. Sie soll abschliessend veranschaulichen, mit welchen Herausforderungen sich Forschende in der Lehrerinnen- und Lehrerbildung in den kommenden Jahren konfrontiert sehen werden.

Schlagworte: Forschung in der Lehrerinnen- und Lehrerbildung, Grossbritannien, Forschungsmethoden, wissenschaftliche Zeitschriften, Forschungsnetzwerke

\section{Recherche sur les formations à l'enseignement en G.-B: les développements les plus récents}

\section{Résumé}

Cet article analyse l'état actuel des recherches menées dans les instituts de formation à l'enseignement du Royaume-Uni. Après avoir brièvement décrit, du point de vue historique, l'ensemble des développements au cours du siècle dernier, les auteurs se penchent sur les projets récents qui visent à améliorer et à développer les capacités professionnelles des enseignants. Ensuite, une base de donnée en ligne, qui rassemble de nombreuses publications éditées de 2000 à 2008 à propos de la formation pédagogique des enseignants au Royaume-Uni, est analysée. Les revues et les auteurs y ayant contribué sont identifiés. Cette analyse bibliographique montre quelles approches méthodologiques et quels domaines prédominent dans le champ de la recherche menées dans les instituts de formation à l'enseignement du Royaume-Uni. Enfin, l'article rend compte des défis auxquels les chercheurs se trouveront confrontés dans les années à venir dans ce champ spécifique. 
Mots clés: Recherches menées dans les instituts de formation à l'enseignement, Royaume Uni, Méthodologies de recherche, Revues scientifiques, Réseau de recherches

\section{La ricerca sulla formazione degli insegnanti in Gran Bretagna: lo stato dell'arte}

Riassunto

Questo contributo analizza lo stato dell'arte della ricerca sulla formazione degli insegnanti in Gran Bretagna. Esordisce con un breve istoriato dell'evoluzione dell'ultimo secolo per poi descrivere alcune iniziative tese a favorire lo sviluppo delle risorse per la ricerca in questo campo. La base dell'articolo è costituita dall'analisi di una banca dati online contenente un numero consistente di articoli scientifici pubblicati sulla ricerca in questione nel periodo 2000-2008. Anzitutto vengono identificati gli autori e la rivista di pubblicazione, per poi passare ad individuare gli approcci metodologici e le problematiche affrontate, tenendo in considerazione la categorie utilizzate dalla banca dati stessa. L'analisi permette di mettere in evidenza le sfide particolari che attendono i ricercatori nei prossimi anni.

Parole chiave: Formazione degli insegnanti, metodi di ricerca, riviste scientifiche, reti di ricerca 